\title{
Rethinking the 'Problem' of Religious Pluralism in Canada and the European Union
}

\author{
Ian Morrison
}

\begin{abstract}
In recent years the nature of secularism and the rights of religious minorities have come to the fore as issues in debates concerning citizenship, multiculturalism and immigration, both in Canada and the European Union. Unlike earlier campaigns of secularization, these recent discourses of secularisation concern not only the institutional separation of Church and State but seek to protect modern secular society from the perceived threat of various externally rooted religious threats through the secularisation of subjects within public spaces. In an attempt to more fully understand this new form of secularisation, the consequences it has had and the debates it has generated in both Canada and the EU, the proposed paper will proceed on four fronts. First, it will outline the earlier discourses and practices of secularisation. Second, the article will posit that we are presently witnessing a different discourse of secularisation, one that is distinct from this earlier form. Third, the article will offer a critique of both discourses, arguing that both involve the deployment of essentialised conceptions of the religious, the secular, and their interaction. Fourth, an alternative approach will be offered, one that seeks to denaturalise the aforementioned categories. The article argues that it is only in this manner that a space and possibility for genuine dialogue concerning secularism and religious pluralism in Canada and the EU can be created.
\end{abstract}




\section{Introduction}

In recent years the rights of religious minorities within secular society has come to the fore as an issue in debates on citizenship, multiculturalism and immigration in both Canada and the European Union (EU). From the controversy provoked by prohibitions on the donning of the hijab in educational institutions in France and Québec, to the banishment of the burqa, the chador, and the niqab from public space in Italy, the Netherlands and several Belgian towns (beginning with Maaseik), to British Cabinet Minister Jack Straw's urging of female Muslim constituents to uncover their faces when communicating with him, there has been increasing calls to limit the right to display religious symbols in public spaces. Much of the opposition to the public display of religious symbols arises from a fear that the religious practices of certain groups primarily those associated with Islam-, as well as the groups themselves, are a threat to social cohesion, democracy, pluralism and modern, democratic society. In response to this perceived threat, various actors have sought to protect secular society through the enactment of policies that delineate the appropriate place of religion and the religious subject in contemporary society. In line with the discourse espoused by these various actors, those considered to be a danger to secular institutions and society as a result of their perceived religiosity, must either be secularised or take on a secular persona in public space.

The recent emergence of religion as a 'problem' in Canadian and European society should not be seen as simply a re-emergence of historical concerns with the place of religion in society and a re-invocation of secularization. In order to point to the 
specificity of the recent problematization of religion in Canada and the European Union, this article will discuss what I call two moments of secularisation: the secularisation of the late nineteenth century and early twentieth century, and the secularisations that have occurred since the early 1990s. In order to grasp and contend with this new secularisation, its consequences, and the debates that it has generated in both Canada and the EU it is necessary to understand these discourses and practices in their historical specificity. The article will proceed on four fronts; first, it will outline the discourse and practices of the first moment of secularisation, examining the manner in which this discourse was deployed, and the ends that it was to achieve. Secondly, it will argue that we are presently witnessing a distinct second moment of secularisation. Thirdly, it will offer a critique of the discourses of both moments, arguing that they involve the deployment of essentialised conceptions of the religious, the secular, and their interaction. Finally, an alternative approach to dealing with these issues will be offered, one that seeks to denaturalize the aforementioned categories. The article will argue that it is only through this approach that a space for genuine cross-cultural dialogue on secularism and religious pluralism in Canada and the EU can be generated.

\section{Secularisation and Secularisations}

By the 1970s, various theories purporting the progressive marginalisation, privatisation and decline of religion owing to the modernization of society had achieved the status of "reigning dogma" in the fields of sociology and the social history of religion (Swatos and Christiano, 1999: 209). Theorists such as Robert Bellah (1964), Peter Berger (1967), Thomas Luckmann (1963), David Martin (1978), and Talcott Parsons (1963) developed systematized and general accounts, as well as empirical studies suggesting that 
the transition from pre-modernity to modernity has led, or will lead to: a) a marked decline in religious beliefs and practices; b) a structural differentiation of society into religious and secular spheres; and c) a marginalization of religion into the private sector (Casanova, 1994: 7, 211).

Relatively quickly this discourse was challenged by authors such as Jeffrey Cox (2003), Robin Gill (1993), Peter Glasner (1977), Jeffrey Hadden (1987), David Nash (2004), and perhaps most vociferously, by Rodney Stark (1999). These authors dismissed the secularization thesis as lacking theoretical sophistication and empirical verification. Rather than a theory, critics asserted that the secularization thesis was a "religion" (Swatos and Christiano, 1999: 212), a "doctrine", a "taken-for-granted ideology" (Hadden, 1987: 588), a "belief” (Nash, 2004: 306), a "story" (Cox, 2003: 205), a "social myth" (Glasner, 1977), or a set of "prophecies" (Stark, 1999: 250). In sum, the secularization thesis was declared an idea that had itself become sacralized (Hadden, 1987: 599).

In recent years, the sociology of religion has been largely reduced to empirical jousting between critics of the secularization thesis and those who continue to rise to its defence, albeit often in a reformulated and limited form (Bruce, 2002; Dobbelaere, 1981; Swatos and Christiano, 1999; Voye, 1999; Yamane, 1997). These debates concerning the accuracy of the secularization thesis have generally involved an exposition of contradictory empirical studies. Both proponents and critics of theories of secularization have undertaken and employed historical and statistical analyses in order to further their claims. These studies have produced largely inconclusive results. 
Rather than engage in this debate through the deployment of secularisation as a transhistorical concept, the following discussion will consider moments of secularisation. Considering secularizations in this manner can take two related forms. First, in the tradition of Nietzsche $(1881 ; 1882 ; 1887)$, Weber (1920), and Löwith (1949), secularisation can be considered the re-orientation of concepts, meanings or ways of being deemed to be explicitly religious or theological towards what is not considered immediately theological or religious. In this form, the term secularisation remains closely related to its original usage, in the sense that it refers to two processes: the canonical process whereby clergy residing in cloisters returned to the 'world', and the historical process of the appropriation and expropriation of church property that followed the Protestant Reformation and the ensuing Wars of Religion (Berger, 1967:106 ; Casanova, 1994:12-13 ; McLeod, 2000:1; Swatos and Christiano, 1999:210; Turner, 2003:350).

Secondly, and closely related, a study of moments of secularisation can take the form of a mode of analysis of specific instantiations of secularisation. This would involve an investigation into the manner in which notions of the secular and secularisation emerge and are deployed, as well as into the effects of such deployments. Consequently, these conceptions of secularisation do not seek to promote or refute the notion of secularisation as a process of religious decline, nor do they seek to offer a more nuanced conception of secularisation as a transhistorical process. Rather, in investigating moments of secularisation it is possible to examine the effects of particular historically specific practices of secularisation without becoming bogged down or distracted by debates concerning the accuracy of secularisation as a transhistorical process, and to avoid some 
of the problematic elements of the secularisation thesis that will be discussed in detail later in this article.

\section{Moment}

In speaking of moment, however, I do not refer to something exclusively temporal; rather, a moment is an assemblage of discourses and practices referring to a common problematic, which can be distinguished from other assemblages. I do not mean to suggest that elements of one moment cannot be located in another; there will always be a transference of elements from one moment to another, but they will always be transformed and re-interpreted in the process. Each moment is comprised of particular instantiations of secularisation. The concept of instantiations is particularly useful as it implies simultaneously an instance and a materialization. As a result, instances are always materialisations of a set of distinct discourses and practices that come about through particular technologies and strategies. For example, the first moment of secularisation, through various technologies and strategies, was instantiated in different ways in France and Germany, while the second moment was instantiated in different ways in France and Québec. Yet, despite intra-moment diversity, it is possible to determine a certain unity in this dispersion.

The discursive unity of a moment is not the result of a shared reference to particular objects, style, concepts or themes. Rather, the unity of a discourse is characterized by what Foucault designates the positivity of discourse (Foucault, 1969:141). The unity of a discourse is such that despite a diversity of oeuvres and books, disputes between individuals, and competition between positions, these exist within a 
common field in which their emergence and interactions are made possible (Foucault, 1969:143). The positivity of discourse is, therefore, the condition of existence common to a limited number of statements. It is the body of anonymous, historical rules, determined in a particular historical and spatial context, that define the possibilities of the actualization of statements, objects, concepts, and modes of enunciation. Positivity, therefore, functions as the historical a priori of discourse (Foucault, 1969: 131,143).

Thus, despite intra-discursive diversity, I argue that the second moment of secularisation can clearly be distinguished from the first moment in three important ways. First, while the discourses and policies of secularisation of late nineteenth and early twentieth century sought to institutionally separate Church and State, the primary focus of the recent moment is the secularisation of subjects within public spaces. To this end, actors have aimed to secularise public spaces by removing the problematic influence of religion, as manifest in religious dress and practices. This recent discourse of secularisation no longer concerns only the control of public institutions, but also the desirability of the subjects that appear in public space. Consequently, this recent instantiation of secularisation is an issue of citizenship, as it concerns the delineation of the characteristics of the ideal citizen, and demarcates who has access to public services and institutions. The ideal citizen, within this discourse, is one who does not allow (private) religious convictions and practices to interfere with their (public) participation in secular society. While the secularisation of the first moment delineated the realm of the citizen by determining the public/polis, the second moment is constituted by practices and discourses concerning the secular nature of the ideal citizen. 
Second, the first moment sought to make possible the attainment of rights and freedoms through limiting the influence of the Church in the social and political affairs of society. In contrast, the second moment has involved a limitation of the scope of pluralism in order to protect universal values, and secularism itself. Thus, the discourses of the second moment posit the paradoxical need to limit pluralism in order to protect pluralism. In doing so, they appeal to a need to protect the universal from the particular; not only must universal or natural rights and values (freedom of speech, women's rights, democracy, etc.) be protected from the perceived particularism of religion, but the secular, as the universal, natural (public/political) subject, must be protected from the effects of particularist religious identities on public conduct. Thus, this new wave of secularisation is implicated in debates concerning the nature and desirability of multiculturalism. Unbridled multiculturalism is perceived as a threat to core, universal societal values.

Third, the first moment of secularisation was primarily directed towards combating the dominant influence of endogenous religious institutions. The second moment has, on the other hand, focussed on the protection of an already-secularised society from infiltration by religious threats that are constructed as exogenous. To this end, the new secularisation is intimately linked to discussions of immigration and integration. The religious practices of immigrants are seen as both an impediment to their integration into secular society and, if unchecked, a threat to that society. This is particularly evident in the recent Dutch immigration requirements obliging applicants to view a two hour long film entitled Coming to the Netherlands, whose contents include nudity and homosexuality, in order to demonstrate their willingness and ability to 
participate in liberal Dutch society. It is also apparent in the implementation of the "Code of Life" in the Québec town of Hérouxville (where no immigrants or ethnic minorities actually reside), which outlines that practices such as stoning are prohibited, and that women should only cover their faces on Halloween. In each of these cases, actors determined that it was necessary to demonstrate to 'foreigners' that they must be willing to put aside their ostensible religious beliefs and practices in order to be welcomed, and integrate into secular society. Thus, religion becomes here not an endogenously generated entity that must be cleansed from the social body, but an external contaminant to an already purified space.

The second moment of secularisation, therefore, should not be seen as simply a re-invocation or continuation of earlier campaigns of secularisation. Rather it should be understood as a distinct set of discourses and practices. This is not say that elements of the first moment are no longer present in the second, but rather that they have been altered or re-directed in a manner that cannot simply be understood as a continuation of a grand socio-historical process of secularisation. In fact, such an understanding only serves to conceal the specificity of these new discourses and practices.

Approaching secularisation through this alternative framework makes possible a discussion of particular historical moments as distinct instantiations of secularisation, without having to locate these moments within a grand historical narrative of religious decline. Rather, it can simply be stated that a particular moment was marked by discourses of secularisation that are fundamentally distinct from others. This is not to suggest that a particular moment does not contain elements or influences from earlier moments or that discourses, nor that elements located within one moment do not play a 
role in a later moment. Rather, it suggests that as a result of historical contingencies and struggles prior discourses become interrupted, reinterpreted and combined with other discourses in order to form a distinct historical object of analysis.

\section{First Moment: Institutional Separation and Structural Differentiation}

Approaching secularisation in this manner makes it possible to consider the distinctiveness of the discourses and practices of the secularisation of the second half of the nineteenth century and the early twentieth century. While an implicit differentiation between the secular and religious can be observed in Ancient Greece (Nancy, 2006), Medieval Europe (Kantorowicz, 1957) and early Christian theology (Pranger, 2006), it was at this moment that political movements and officials in several European states enacted reforms that clearly delineated the religious and the political spheres, resulting in the normalization of this differentiation. Through the Cavour Reforms of the 1840s and the 1850s in Piedmont, the Kulturkampf of the 1870s within the German states, the reforms of the French Third Republic, the programs of the Progressive Party in Spain following the revolutions of 1854 and 1868, as well as initiatives in other European states, the structural separation of Church and State was consolidated. It was with this institutionalization of secularisation that being political came to be the grounded in the secular.

The aforementioned included several features, including the expropriation of church property, the recognition of religious pluralism, and the exertion of state control over institutions that were previously under the tutelage of the Church particularly and most successfully educational institutions. Within educational institutions, this involved not only state control over the institutions themselves, but often also an increased 
emphasis on civic instruction as a moral guide for citizens. In this manner, the societal functions of Church and State were delineated, and a properly religious sphere, distinct from civic and other social spheres was constructed. Further illustrative of the differentiation of the religious and secular spheres are the attempts within some states to specifically prohibit the Church or religious figures from engaging in political affairs. For instance, in 1871 an addition was made to Section 130 (Agitation of the People) of the German Criminal Code (Strafgesetzbuch) providing for a penalty of up to two years in prison for clergy who discussed politics from the pulpit.

The enactment and promotion of civil ceremonies to mark rites of passage was another strategy through which the public and the religious were differentiated and contrasted. In Germany in 1875, for example, civil marriage was introduced and religious ceremonies were made voluntary, private affairs with no legal standing. Such a provision clearly separated the legal from the religious, giving precedence to the former and restricting the later to the realm of the private.

Initiatives were also undertaken in various states in order to break what was seen as the Church's monopoly over death rites. In Paris during the 1860s, groups influenced by the ideas of Auguste Blanqui began to organize civil funerals as an alternative to Catholic services (Kselman, 1995:181). Between 1881 and 1904 the French government also passed various laws removing Church control over cemeteries, which had previously been used by clergy as a means of enforcing religious discipline (Kselman, 1995:181; Kselman, 2003:153). Throughout the 1870s, cemeteries were increasingly moved from their location beside Churches to regulated, walled-in areas on the outskirts of towns (Kselman, 1995:184). Moreover, in 1877 the right to a civil burial was enshrined in 
French law. By the early twentieth century approximately forty percent of burials in Paris involved civil ceremonies (McLeod, 1995:18). Such measures concerning rites of death served not only to expand the functions of the state but also limit the influence of the Catholic Church over the population.

The emergence of state funerals is similarly indicative of the state's attempt to usurp Church control over death rites. In 1877, the French state attempted to legitimize and consolidate the Republican regime through the institution of rituals designed to promote devotion to the Republic. Amongst the most prominent of these rituals was the state funeral. Combining aspects of both the previously mentioned Blanquist civil burials and Catholic services, state funerals sought to create and honour national heroes. The ceremonies made use of state institutions and monuments such as the Invalides, the Arc de Triomphe and the Panthéon (Kselman, 1995: 183). The 1885 state funeral and entombment in the Panthéon of Victor Hugo, which was attended by over one million individuals (Kselman, 1995:183; Kselman, 2003:153), can be seen as the apex of the legitimacy of civil burial in France. Through the institution and persistent enactment of civil rites of passage, European states were able to further associate religion with the private sphere and the state with the public sphere.

Attempts to prioritize the state within the public sphere can also been seen in architectural reforms undertaken during the second half of the nineteenth century. Particularly demonstrative of this are Georges-Eugène Hassmann's massive renovation of Paris between 1858 and 1870. Two aspects of these reforms are particularly striking. First, the number of state buildings proliferated. For instance, each of Paris's twenty arrondissements were given a prominent town hall. Second, Haussmann's intentions 
notwithstanding, with the creation of wide boulevards and green spaces, civic buildings and monuments attained visual prominence over the once dominant Churches.

While many of Haussmann's reforms continued to be implemented following the emergence of the Third Republic, this new political regime also contributed to the secularization of public spaces with a rapid multiplication of the number of public monuments dedicated to heroes of the Republic. Central to this was the raising of statues dedicated to local heroes in towns and arrondissements. As Thomas Kselman (1995) suggests, the presence of these monuments in prominent public areas was meant to remind citizens of their obligations to the Republic. However, as with Haussmann's reforms, the construction of these civil monuments also served to further populate a public sphere, previously dominated by buildings and monuments associated with religion, with monuments of the state, the Republic and the nation. In doing so, a further consolidation of an association of the state with the public sphere was permitted to occur. This is particularly evident in the "cult of Marianne", which materialized through the erection of immense statues of Marianne in public spaces, and through the placing of busts in city halls throughout France (Kselman 1995:183-184). Thus, not only were public spaces increasingly marked by prominent civic buildings, these buildings themselves were marked by symbols of the state.

Not only did the construction and prioritization of civic monuments create a link between the state and the public sphere, but in attaching these monuments to rituals of commemoration, the public sphere was firmly established as a site of civic rituals. While the Church was relegated to the site of voluntaristic private ceremonies, the public sphere 
became the site of state funerals, military parades, and commemorations of what were constructed as national events.

It is important to note that the initiatives of secularisation undertaken in the second half of the nineteenth century were not simply the result of a dominance of liberal or radical thought. In fact, as some of the examples from above demonstrate, some of the most stringent measures of secularisation were instituted in Germany during the reign of Bismarck. Moreover, the presence of these measures of secularisation does not correspond to a decrease in levels of religious belief among the European population. As Hugh McLeod has noted, rather than being the result of widespread anticlericalism, strict policies of secularisation often resulted in "a closing of ranks and an increased sense of loyalty to the clergy" (McLeod, 1995:28). What can be observed in this period is a problematization of the dominant role of religion in public life shared by liberals, radicals and secular conservatives. For these actors, religion was a threat to the state, both politically, and as a threat to the social cohesion of the populace. Moreover, for many of these actors, the ascendancy of the Church was a stultifying obstacle to social progress, to the advancement of knowledge, and to individual freedom. To counteract these threats and promote the advancement of human potential, these actors sought, through the measures mentioned above and many others, to reduce the influence of the Church in society, particularly in the public sphere. In doing so they contributed to the institutionalization and normalization of a clear distinction between the religious and civil realms. 


\section{Second Moment: The Secularisation of the Public Subject}

The most prominent and recurrent of the purported goals of the campaigns of secularisation which took place in the later half of the nineteenth and early twentieth centuries was an increase in individual freedom and autonomy through a reduction of the dominance of the Church outside the religious sphere. The institutional separation of Church and State was meant not only to allow the State to concern itself solely with the concerns of this world, and thus act in a more rational and effective manner, but the privatization of religion was meant to support freedom of conscience, promote the rights of religious minorities, and permit "a free market in opinions" (Chadwick, 1975:27). By the late twentieth century, however, the freedoms that these earlier reforms enabled began to be seen as a threat to secularism itself. The claim was made that in reducing the dominance of the Church individuals would have the opportunity to exercise rights to freedom of speech, conscience, and religion. Recently, however, as is evident in various cases of across Canada and the EU, attempts by individuals and groups to exercise these rights have come to be perceived as a threat to secular society itself.

In the last decades of the twentieth century concerns of a purported return of religion were raised with greater frequency (Dallmayr, 1999). Anxieties regarding what was seen as a rising tide of fundamentalism, most often in an Islamic guise, were voiced with increased urgency. Since the 1990s, the focus of worries in Canada and many of the member states of the European Union surrounding this purported return of religion came to involve issues of domestic rather than international affairs. During this period, the overriding concern regarding the return of religion transformed from one involving external threats in the form of the anti-western theocratic regimes such as Iran and 
foreign Islamist terrorists, to the threat posed by "home-grown terrorists", and the religious beliefs of recent immigrant populations, particularly Muslims. ${ }^{1}$

This problematization of the presence of Muslim symbols and the Muslim subject of whom they are manifestations, although calling upon elements of the discourse and practices of nineteenth and early twentieth century secularisation (as well as the process of secularization which was undertaken as part of Québec's Quiet Revolution), should not be seen as to a continuation of the purported transhistorical process of secularisation or merely a variation of intra-discursive themes. To do so would serve to conceal the specificity of this contemporary problematization and, as will be argued later on, create obstacles for the development of meaningful dialogue. The problematization of the religious subject in recent years, however, should also not be seen as a moral panic provoked by certain conservative, racist, and xenophobic elements within Canadian and European society. While such voices have often tended to garner the most attention, the 'problem' of religious, particularly Muslim immigrants has been raised in many spheres. While disagreeing with the many overtly racist premises of anti-Islamic discourse, liberal, socialist and feminist voices have at times been at the forefront of the articulation of the vital need to contend with issues of Islamic fundamentalism, the social integration of Muslim immigrants, and the need to determine reasonable accommodation for religious minorities. In France, for instance, teachers associated with Lutte Ouvrière and the Revolutionary Communist League as well as Socialist Ministers Laurent Fabius and Jack Lang were among the voices calling for a prohibition on the hijab in the classroom.

\footnotetext{
${ }^{1}$ Of course, as Marie-Blanche Tahon (1996: 172) argues, the popularization during the early 1990s of concerns about human rights in states such as Algeria is not unrelated to a growing suspicion of Muslim symbols and subjects in Western States during the same period.
} 
As the recent cases demonstrate, public displays of religious symbols and practices are not perceived as an enactment of rights made possible by the existence of a secular public sphere. They are increasingly perceived as a religious threat to secular society. Thus, one can observe the emergence of a new discourse that claims that secular society needs to be protected from this threat. Within this new discourse, the protection of society from this religious threat is to be accomplished by a secularisation of the subjects present in public space. This secularisation is carried out by reminding members of immigrant and minority religious groups of, and when necessary legislating the acceptable limits of the demonstration of religious difference in the public sphere.

Fundamental to this new discourse is the normalization and valourization of the secular subject. The secular subject is positioned as normal, neutral and natural in relation to its abnormal, deviant, and unnatural religious subject. Borrowing from elements of the Enlightenment, secular knowledge is depicted as the natural rational way of knowing to be attained when light is shone on the shadows of religious superstition. The secular subject is portrayed as the natural and neutral subject that exists in the absence of the alienating influence of religion. This transcendental subject is not conceived of as historically constructed but as transcendental, not produced but unveiled through a historical struggle against the domination of religion.

The secular subject, secular knowledge and secular society appear as normal in various senses of the word: (1) As pure in the absence of the contaminating exterior influences of religion; (2) As natural, as opposed to the contrived character of religion; (3) As neutral and universal, as opposed to the particularizing and divisive effect of religion; and (4) As standard, as opposed to peculiar. The formulation of the secular 
subject as natural, rational, free and modern provides justification for the exclusion of those who do not conform to these standards, casting them out of what Marilyn Friedman has dubbed "the legitimation pool" (Friedman, 2000:196). The normalization of the secular subject legitimates the exclusion of those who cannot bracket and set aside comprehensive moral and religious doctrines in order to engage in neutral and objective deliberations (Sandel, 1998). Thus, the construction of the secular subject as norm permits racial, ethnic and religious exclusions to be cloaked in the language of irrationality and inability to adapt to modern society, and justifies such measures as necessary for the protection of progressive modern values.

\section{Opening a Dialogue: Rethinking the Secular and the Religious}

Crucial to the dominance of the ideas guiding the two moments of secularisation is the interpretation and theorization of secularisation in the social sciences. Within the social sciences, the dominant interpretation of secularization as a transhistorical phenomena has been largely taken for granted. Moreover, social scientists have attempted to provide theoretical support for the ideas guiding the practices of secularisation, through the formulation of what has come to be known as the secularisation thesis. Prominent thinkers that can be associated with the secularisation thesis include Robert Bellah (1964), Peter Berger (2002), Steve Brice (2002), Talcott Parsons (1963; 1964), Bernard Lewis (1961), Thomas Luckmann (1963), David Martin (1978), Barrington Moore (1966), and Bryan Wilson (1966). By the early 1970s, these

accounts had come to be seen as the only valid interpretation of religious change within the social sciences (Swatos and Christiano, 1999:209). Through the deployment of notions of differentiation, capitalisation, urbanisation, and rationalisation these thinkers 
sought to demonstrate a positive interrelation between the decline of religious belief and influence to the modernisation of society. Secularisation was considered to be the normal historical path for modernising nations. Correspondingly, the secular subject is seen as the modern norm, contrasted with the religious norm of pre-modern society, and as developing teleologically through the process of modernization. The secular subject and secular society are portrayed as natural and normal within modern society, as opposed to the unnatural and abnormal place of religion as an historic remnant in modern times. Moreover, many of these thinkers sought to demonstrate that such change was inherently positive, as they took for granted the claims that secularization necessarily brought about more individual freedom.

As the recent debates concerning religious pluralism have demonstrated, the relationship between secularisation and individual freedom is not as unproblematic as it was portrayed by the social sciences. Furthermore, the normalization and naturalization of the secular and secularization have served to obscure or at least mitigate the response to the limitations of minority rights involved in recent measures of secularisation. The creation of such natural universal categories always serves to problematize or mask difference, the difference that is necessarily present in but often obscured by these very universals. Thus, we need to disrupt the relationship between secularisation and individual freedom and denaturalise their positive correlation.

These theoretical conceptions of secularisation, while seemingly purely abstract, are in fact intimately related to present day practices of secularisation. They provide both the impetus for, and justification of the various practices that have recently been 
witnessed. It is crucial, therefore, to engage with these ideas in order to develop new approaches to the problems of religious pluralism.

One of the central limitations of these conceptualizations of secularization is their essentialisation of the secular and the religious. Rather than investigating how certain objects and subjects came to be constructed as religious or secular, problematic and normal, theories of secularisation view these categories as given, unquestionable and ahistoric. Moreover, in approaching these categories as necessarily oppositional, the possibility of engagement between the so-called secular and religious camps is nullified. This is precisely what leads to the perception that, for instance, one cannot wear the hijab while at the same time participating fully as a citizen, and engaging as a citizen with others in the public sphere.

In order to open a space for genuine cross-cultural dialogue, rather than a paring of competing monologues, it is necessary to clarify the process through which groups and individuals have come to invest themselves in certain concepts and values. A study of the problematization of religious symbols and practices should not approach these symbols and practices as essentially religious or contrary to secularism, but as constructed as such as a consequence of numerous historical struggles. As Talal Asad (1993; 2003) and John Milbank (2006) have demonstrated, the categories of the religious and the secular, as well as particular practices related to them, emerged historically as the result of various contingent struggles and interpretations. Moreover, as Brian Turner (2003) has demonstrated, the boundary and relationship between the secular and the religious is fluid. The exclusion of particular practices and symbols, and the religious 
subject they represent, emerge from various intersecting technologies of differentiation and problematization.

Approaching the religious, the secular and their interaction as historical, fluid concepts allows for a novel approach to issues of religious pluralism, one that challenges discourses of cultural incommensurability that naturalize and justify exclusionary practices through an uncritical association of the secular with autonomy, enlightenment and modernity, and religion with heteronomy, ignorance and pre-modernity. Contestations regarding limitations of diversity and accommodation, such as the contemporary cases that problematize religion as a threat to secular society in Canada and the EU, frequently entail an invocation of the immutability of particular values. This often involves the deployment of particular histories of struggle as an alibi for debate and dialogue. The use of rigid, ahistorical categories such as the religious and the secular in the formulation of historical narratives and their implementation into these debates often leads only to misrecognition. In order to permit debate on those categories and values that appear unquestionable, it is necessary to offer alternative histories, histories that point to the contingencies of these categories and values, the forces involved in their emergence, interpretation and reinterpretation, and thus, histories that de-normalise and de-naturalise that which claims to be normal, natural and unquestionable 


\section{Bibliography:}

Asad, Talad. 1993. Genealogies of Religion: Discipline and Reasons of Power in Christianity and Islam. Baltimore: John Hopkins University Press. . 2003. Formations of the Secular: Christianity, Islam, Modernity. Stanford: Stanford University Press.

Bellah, Robert N. 1964. Religious Evolution. American Sociological Review, 29(3), 35874.

Berger, Peter. L. 1967. The Sacred Canopy: Elements of a Sociological Theory of Religion. New York: Anchor.

Bruce, Steve. 2002. God is Dead: Secularization in the West. Oxford: Blackwell.

Casanova, Jose. 1994. Public Religions in the Modern World. Chicago: University of Chicago Press.

Chadwick, Owen. 1975. The Secularization of the European Mind in the Nineteenth century: The Gifford Lectures in the University of Edinburgh for 1973-4. Cambridge: Cambridge University Press.

Cox, Jeffery. 2003. Master Narratives of Long-Term Religious Change. In H. Mcleod, \& W. Ustorf (Eds.), The Decline of Christendom in Western Europe, 1750-2000. ( 201-17). Cambridge: Cambridge University Press.

Dallmayr, Fred. 1999. Rethinking Secularism (With Raimon Panikkar). The Review of Politics, 61(4), 715-35.

Dobbelaere, Karel. 1981. Secularization: A Multi-Dimensional Concept. Current Sociology, 29(2), 3-153.

Foucault, Michel. 1969. The Archaeology of Knowledge. London: Routledge.

Friedman, Milton. 2000. John Rawls and the Political Coercion of Unreasonable People. In D. V. Wolf, \& C. Wolf (Eds.), The Idea of Political Liberalism: Essays on Rawls. (pp. 16-33). Oxford: Rowman and Littlefield.

Gill, Robin. 1993. The Myth of the Empty Church. London: Society for Promoting Christian Knowledge.

Glasner, Peter. E. 1977. The Sociology of Secularisation: A Critique of a Concept. London: Routledge. 
Hadden, Jeffrey. K. 1987. Towards Desacralizing Secularization Theory. Social Forces, 65(3), 587-611.

Kantorowicz, Ernst. 1957. The king's two bodies; a study in mediaeval political theology. Princeton, N.J: Princeton University Press.

Kselman, Thomas. 1995. The Varieties of Religious Experience in Urban France. In H. McLeod (Ed.), European Religion in the Age of Great Cities, 1830-1930. (pp. 16590). London: Routledge.

. 2003. The Dechristianisation of Death in France. In H. Mcleod, \& W. Ustorf (Eds.), The Decline of Christendom in Western Europe, 1750-2000. (pp. 145-62). Cambridge: Cambridge University Press.

Löwith, Karl. 1949. Meaning in history; the theological implications of the philosophy of history. [Chicago]: Univ. of Chicago Press.

Luckmann, Thomas. 1963. The Invisible Religion: The Problems of Religion in Modern Society. New York: Macmillan.

Martin, David. 1978. A General Theory of Secularization. Oxford: Blackwell.

McLeod, Hugh. 1995. Introduction. In H. McLeod, \& W. Ustorf (Eds.), The Decline of Christendom in Western Europe, 1750-2000. Cambridge: Cambridge University Press.

2000. Secularisation in Western Europe, 1848-1914. New York: St. Martin's Press.

Milbank, John. 2006. Theology and social theory: beyond secular reason (2nd ed.). Oxford, UK ; Malden, MA: Blackwell Pub.

Moore, Barrington. 1967. Social origins of dictatorship and democracy: lord and peasant in the making of the modern world. London: Penguin.

Nancy, Jean-Luc. 2006. Church, State, Resistance (V. Voruz, Trans.). In H. d. Vries, \& L. E. Sullivan (Eds.), Political Theologies: Public Religions in a Post-Secular World. (pp. 102-12). New York: Fordham University Press.

Nash, David. 2004. Reconnecting Religion with Social and Cultural History: Secularization's Failure as a Master Narrative. Cultural and Social History, 1, 30225 .

Nietzsche, Friedrich. 1881. Daybreak: Thoughts on the Prejudices of Morality (R. J. Hollingdale, Trans.). Cambridge: Cambridge University Press. 
.1882. The Gay Science (J. Nauckhoff, Trans.). Cambridge: Cambridge University Press.

. 1887. On the Genealogy of Morality. K. Ansell-Pearson (Ed.). Cambridge: Cambridge University Press.

Parsons, Talcott. 1963. Christianity and Modern Industrial Society. In E. A. Tiryakian (Ed.), Sociological Theory, Values, and Sociocultural Change: Essays in Honour of Pitrim A. Sorokin. (pp. 33-70). New York: Free Press. Beacon.

. 1964. Introduction. The Sociology of Religion. (pp. xxix-lxxvii). Boston:

Pranger, M. B. 2006. Politics and Finitude: The Temporal Status of Augustine's Civitas Permixta. In H. d. Vries, \& L. E. Sullivan (Eds.), Political Theologies: Public Religions in a Post-Secular World. (pp. 113-21). New York: Fulham University Press.

Sandel, Michael. 1998. Liberalism and the Limits of Justice. Cambridge: Cambridge University Press.

Swatos, William. H. \& Christiano, Kevin. J. 1999. Secularization Theory: The Course of a Concept. Sociology of Religion, 60(3), 209-31.

Tahon, M.-B. 1996. Regards croisés sur les musulmanes au Québec. In K. Fall, R. HadjMoussa, \& D. Simeoni (Eds.), Les convergences culturelles dans les sociétés pluriethniques. (pp. 169-88). Sainte-Foy: Presses de l'Université du Québec.

Turner, Brian S. 2003. Historical Sociology of Religion: Politics and Modernity. In G. Delanty, \& E. F. Isin (Eds.), Handbook of Historical Sociology. (pp. 349-63). London: SAGE.

Voye, Liliane. 1999. Secularization in a Context of Advanced Modernity. Sociology of Religion, 60(3), 275-83.

Weber, Max. 1920. The Protestant Ethic and the Spirit of Capitalism (T. Parsons, Trans.). Los Angeles,: Roxbury.

Yamane, David. 1997. Secularization on Trial: In Defense of a Neosecularization Paradigm. Journal for the Scientific Study of Religion, 36(1), 109-22. 